\title{
EL LECTOR FICTICIO EN LA OBRA DE ANTONIO MUÑOZ MOLINA
}

\author{
José Manuel Begines Hormigo \\ Universidad de Sevilla
}

\begin{abstract}
RESUMEN
En este artículo, se aplica a la obra de Antonio Muñoz Molina la teoría del lector ficticio, desarrollada por autores como W. Iser y H. Link. El autor ubetense utiliza en su obra, fundamentalmente, dos tipos de lector ficticio: el lector-detective que debe actuar en la obra como un verdadero investigador que reúne todas las pistas para llegar a una resolución final; el lector pasivo, que actúa como un lector extratextual, limitándose a rellenar, imaginativamente, las lagunas de las historias que se narran en las novelas del autor

Palabras clave: Lector, Teoría de la Literatura, Antonio Muñoz Molina, Novela

\section{ABSTRACT}

In this paper, the theory of the inscribed reader is applied to the work of Antonio Muñoz Molina, developed by authors like W. Iser and $H$. Link. The ubetense author uses in his work, fundamentally, two types of inscribed reader: the reader-detective who must act in the novels like a true investigator who collects all the tracks to arrive at a final resolution; the passive reader, who acts like an extratextual reader, limiting itself to fill up, imaginatively, the gaps of histories that are narrated in novels of the author
\end{abstract}

Keywords: Reader, Literature Theory, Antonio Muñoz Molina, Novel.

El concepto de lector ficticio fue desarrollado por H. Link a partir del proceso de la comunicación literaria fijado por W. Iser ${ }^{1}$, para quien la comunicación literaria concluía al producirse la implicación del lector. Link, aprovechando el concepto creado por Iser de lector implicado, desdobló este concepto en dos facetas distintas: la extratextual y la intratextual. Reservó para el

${ }^{1}$ Vid. W. Iser, "El proceso de lectura: enfoque fenomenológico", en J. A. Mayoral (comp.), Estética de la recepción, Madrid, Arco/Libros, 1987, pp. 215-243. 
primer nivel el calificativo de implicado, y llamó lector ficticio al que existe en el nivel textual de la obra ${ }^{2}$. El lector ficticio ${ }^{3}$ es el destinatario, incluido en la obra, al que se le dirige la narración principal o al que, esporádicamente, se le cuentan diversas historias o partes de la historia principal. Uno de los pilares fundamentales de la narrativa moliniana es la importancia que el novelista atribuye a la oralidad en su obra. De hecho, en sus novelas, aparecen constantemente personajes enfermos de ficción que sienten la necesidad de contar sin parar. Para que esos personajes cuenten, evidentemente, debe haber otros personajes que escuchen y que estén interesados en que le sigan contando una historia. Ésos son los lectores ficticios de las novelas, según la terminología de Link. Desde su primera novela -Beatus ille-, hasta su última obra -El viento de la Luna- el novelista no ha dejado de utilizar a personajes como destinatarios de las historias que son contadas en la novela.

La manera en que usa esos lectores ficticios, sin embargo, no siempre es igual. En algunos casos, en sus primeras novelas sobre todo, aparece un tipo de lector que actúa como un investigador, un personaje que debe ganarse la historia por medio de sus pesquisas. No escucha cómodamente y sin implicarse lo que alguien le está contando, sino que debe indagar por su cuenta, utilizar las pistas que va encontrando, poco a poco, a lo largo del desarrollo de la novela, atar cabos y, como si fuera un lector real, extratextual, rellenar las lagunas (o espacios vacíos según decía Iser $\left.^{4}\right)$ que existen en las versiones que le han ido contando para, después, lograr llegar al desenlace correcto. Lawrence Rich habla de este mismo tipo de personajes en la obra del ubetense, pero recorre el camino inverso al seguido aquí. Él compara los detectives de las novelas con el lector, puesto que debe actuar de la misma forma: "In his search for the criminal, the detective acts as a «reader» who must construct a narrative version of crime from a number of clues in an indecipherable «text»" ${ }^{5}$. Aquí se sostiene la situación contraria, el de lectores ficticios que, atrapados por las historias que les cuentan, se han convertido en detectives. De cualquier forma, el resultado es similar: personajes que actúan dentro de la novela como rastreadores de pistas que utilizan luego para elaborar una historia y otorgarle un desenlace. Herzberger sí habla, específicamente, de lector-detective. Las palabras que destina a Beatus ille pueden

${ }^{2}$ Vid. L. A. Acosta Gómez, El lector y la obra, Madrid, Gredos, 1989, pp. 223-224.

${ }^{3}$ Conocido también como narratario.

${ }^{4}$ Vid. W. Iser, art. cit., p. 233.

${ }^{5}$ L. Rich, The narrative of Antonio Muñoz Molina. Self-Conscious Realism and "El Desencanto", New York, Peter Lang, 1994, p. 66. 
ser utilizadas, también, para El invierno en Lisboa o Beltenebros: "In Beatus ille the way of telling the story is to entice Minaya into the mystery and to compel him to play the role of reader/detective" 6 .

Frente a este tipo de lector ficticio (lector-detective), se puede encontrar en la obra de Muñoz Molina otro tipo de lector. Es un lector acomodado que simplemente va escuchando lo que alguien le cuenta, sin tener que desarrollar ningún tipo de investigación activa, física, sino que actúa como cualquier lector de un nivel extratextual: se deja atrapar por el atractivo de la historia, pero su función es, únicamente, la de escuchar, entender y recrear en su mente el mundo creado por las palabras del narrador. Esta pasividad del lector intratextual, sobre la que habrán de hacerse ciertas matizaciones, tiene lugar, sobre todo, en El jinete polaco, Los misterios de Madrid o Carlota Fainberg.

Sin establecer claramente una clasificación -como se ha hecho aquí entre lector-detective y lector-acomodado-, Lawrence Rich percibe los dos tipos de lectores dentro de la producción literaria del novelista. Él defiende que los lectores inscritos (inscribed readers) actúan en sus novelas efectuando las mismas operaciones que un lector real. De esta manera, se refiere a Darman, que es uno de esos lectores-detectives que actúan mientras son receptores de una historia, y que se esfuerzan, a veces, aunque son incapaces de hacerlo, por rellenar los huecos existentes:

[Darman] can also be seen as an inscribed reader, lost in a textual world that he cannot "read" [...]. When Darman finds the older Rebeca writing on "una máquina de escribir donde no había ningún papel”, the absence of paper [...] is like Lucrecia's letter emblematic of the "gaps" that Darman has encountered throughout the novel ${ }^{7}$.

Es significativo que Rich utilice, para referirse a los pasos que debe seguir el asesino Darman, el mismo término que Iser crea para hablar de las lagunas que el lector tiene que rellenar si quiere efectuar una lectura significativa de una obra literaria. Darman, igual que Biralbo en El invierno en Lisboa e igual que Minaya en Beatus ille, se convierte en detective y receptor-oyente de una historia.

Rich también hace referencia al segundo de los grupos que se establece en este trabajo: aquel compuesto por los personajes lectores que actúan como un verdadero lector extratextual, atento sólo a las palabras que alguien cuenta, sin necesidad de actuar de una manera física, sino únicamente intelectual. Dentro de

${ }^{6}$ D. K. Herzberger, "Reading and the Creation of Identity in Muñoz Molina's Beatus ille", Revista Hispánica Moderna, L.2 (1997), p. 386.

${ }^{7}$ L. Rich, op. cit., p. 72. 
este grupo se engloba a los personajes lectores de El jinete polaco. Rich, en cambio, parece que compara a Manuel, protagonista de la obra maestra del jienense, con Darman o Biralbo:

In El jinete polaco, Manuel offers another case o an inscribed reader confronted with "text" which include photographs, conversations, memories, letters and don Mercurio's Bible. Manuel "reads" to reconstruct the story of his past, and also plays the role of a detective who, by interrogating Julián, finally solves the mystery of the mummy ${ }^{8}$.

No es descabellado el planteamiento de Rich: Manuel lee las fotografías heredadas por Nadia, la Biblia protestante que en su día fue del médico don Mercurio, rememora hechos pasados, se identifica con "El jinete polaco" de Rembrandt, y luego, después de haber sido el receptor de todos esos datos -el lector ficticio de todos esos datos - se convierte en detective para descubrir el misterio de la emparedada. A pesar de este planteamiento bien engarzado, Rich pasa por alto un dato fundamental. Y es que Manuel, a lo largo de toda la novela no es el receptor, sino el emisor de una historia que le cuenta a Nadia, la verdadera lectora ficticia, la verdadera inscribed reader, de la novela. Sí es verdad que Manuel durante su infancia fue receptor de toda la tradición oral transmitida de padres a hijos; sin embargo, en su adultez se ha convertido, gracias a las inquisiciones de Nadia, y a la estabilidad sentimental que le proporciona, en un emisor de palabras y, con ello, enlazó de nuevo con las raíces de una tradición oral y popular' ${ }^{9}$. Por eso, las palabras de Rich se quedan en el primer estadio del crecimiento de Manuel -en la etapa primera de la recepción -, sin llegar hasta el punto determinante de la obra: el momento en que Manuel deja de ser un mero transmisor de palabras que no entiende, las de aquellos idiomas que traducía instantáneamente sin prestarles atención, para convertirse en un eslabón imprescindible, y recreador, de la tradición oral de su familia. Su aporte fundamental -y ahí tiene Rich toda la razón- es haber añadido un punto importante, después de su encuentro con Julián, a la historia de su bisabuelo

\footnotetext{
${ }^{8}$ Ib., p. 72. También habla de inscribed reader en el caso de Marino, el protagonista del cuento "La poseída": "Marino in «La Poseída» (Nada del otro mundo) is, like a real reader, faced an enigmatic «text»-the girl in the bar. [...] Marino is therefore depicted as an inscribed reader, but an incompetent one guilty of misreading. It should be noted that although «La Poseída» is not a detective story, its title is also a clue for the extratextual reader, one which can only be understood retroactively: the girl is "possessed» not by love, but by her drug habit” (Ib., p. 70).

${ }^{9}$ Vid. J. M. Begines Hormigo, Personajes y estilo en la narrativa de Antonio Muñoz Molina, Sevilla, Padilla Libros, 2006, p. 134 y ss.
} 
Pedro Expósito Expósito en relación con la emparedada y el médico don Mercurio.

Para hablar de los lectores ficticios del primer grupo, deben tenerse en cuenta unas palabras de Latorre Madrid. En su libro, refiriéndose a la novela Beatus ille, que él analiza desde la perspectiva genérica de la metanovela, compara a Solana y Minaya con los lectores reales. Dice que "al igual que Solana y Minaya, el lector tiene que hacer una labor de reconstrucción de la historia que se nos cuenta, completando de esta manera el proceso" ${ }^{10}$. Estas palabras, aplicadas a los personajes de Beatus ille, cuadran a la perfección con los lectores ficticios de El invierno en Lisboa y Beltenebros. Santiago Biralbo -aunque ya se analizará en profundidad- es un detective, como Minaya, que va leyendo las pistas que Lucrecia y los villanos le van facilitando; Darman, también, es un cazador de pistas, un lector de huellas que, de vez en cuando, consume las novelas pertenecientes al género rosa que Rebeca Osorio, madre, publicaba con consignas secretas.

El lector ficticio fundamental de Beatus ille es Minaya. Desde el momento en que el joven llega desde Madrid huyendo de los grises, se convierte en el detective de unos hechos que sucedieron durante la guerra civil española. Hay que destacar que Minaya, supuestamente, está haciendo la tesis sobre el escritor Jacinto Solana, poeta perteneciente a la generación del 27 e injustamente silenciado. Hacer una tesis doctoral implica un proceso de lectura y de investigación que convierte al doctorando en un lector esponja que lo aprovecha todo. Esto es exactamente lo que le ocurre a Minaya: se interesa tanto por el tema de su tesis fingida, que acumula los datos proporcionados por todos los habitantes de la casa-palacio de su tío: doña Elvira, su tío Manuel, la sirvienta Inés, el médico Medina, el escultor Utrera, etc. Además, busca los manuscritos de Solana y recorre sus pasos por la ciudad de Mágina. Minaya es el lector y recopilador de una serie de circunstancias y, en cierta manera, el creador de la historia, de Beatus ille, porque sin él, esos testimonios no se habrían ordenado ni habrían tomado la forma de una novela.

Esta última afirmación no debe sacarse de quicio. En la persona de Minaya se compendia toda la historia que, de otra forma, sólo habría sido una serie de conversaciones desenlazadas. Por otra parte, Minaya actúa igual que cualquier lector extratextual, rellenando los vacíos del texto (o de los testimonios y los manuscritos en el caso de Minaya) y, por ello, "creando" la novela. El verbo

${ }^{10}$ M. A. Latorre Madrid, La narrativa de Antonio Muñoz Molina. Beatus ille como metanovela, Málaga, Universidad de Málaga, 2003, p. 93. 
"crear" debe tomarse en el sentido de terminar de conformar la historia, simplemente, sin pretender que Minaya sea el verdadero creador de la novela. Esto es precisamente lo que se propone demostrar J. Prieto:

Minaya [...] funcionaría como un trasunto del lector, auténtico «iniciador» de la escritura, que no empieza cabalmente sino con el acto de la lectura. Así, la novela «que no ha necesitado ser escrita para existir» no es ya sólo «Beatus ille», que existe en la imaginación del detective/lector intratextual Minaya, sino también Beatus ille, que existe en la imaginación del lector extratextual, a través del acto creador de la lectura: la novela no necesita ser escrita porque es el lector el que la «escribe» de modo que, al leer, está escribiendo lo que el autor no escribió, segregando «páginas no escritas», como el falso escritor Solana confiesa al «lector» Minaya: «Ahora mismo su desengaño y su asombro siguen escribiendo lo que yo no escribí, segregan páginas no escritas», donde ese «ahora mismo» alude [...] tanto al momento intratextual de la confesión como [...] al «ahora» extratextual, histórico, de la lectura ${ }^{11}$.

La teoría, a veces, avalada por otras teorías -la de la metaficción o la de los géneros postmodernos, en este caso-, puede oponerse al sentido común y a la práctica más pedestre y cotidiana. La afirmación de que la novela no ha sido escrita se opone a la realidad. Por tanto, cuando Solana dice que Minaya sigue escribiendo lo que él no escribió, está indicando, claramente, que algo escribió. La tarea del lector, entonces, más que escribir la novela es, según mantenía Wolfgang Iser, completar lo que el creador omitió para establecer con él una relación de compenetración.

Las afirmaciones de Prieto son acertadas en cuanto a lo que se refiere a la complejidad estructural de Beatus ille. Muchos críticos han tratado de aclararla, pero no existe un acuerdo. La teoría más razonable parece ser la que concluye que quien escribe realmente la novela, quien la narra, es Minaya. Pero no simbólicamente, como sostiene Prieto, sino literalmente. Entonces, si esto es así, Minaya aprovecha los manuscritos de Solana para, a través de ellos, escribir, literalmente, la novela. En este caso, tendría que imaginar el suicido y los pensamientos de Jacinto Solana antes de morir. Es ésta una estructura de muñeca rusa donde Minaya imagina -y escribe - que Solana imagina que Minaya imagina su suicidio.

De las palabras de Prieto, por tanto, son acertadas aquellas que se refieren a la cualidad lectora de Minaya, quien, efectivamente, lee el "Beatus ille" inédito y se convierte en creador literal de la novela que Solana no fue capaz de escribir en

${ }^{11} \mathrm{~J}$. Prieto, "«Playing the sedulous ape»: Antonio Muñoz Molina y los espejos de la (meta)ficción en Beatus ille", Revista de estudios hispánicos, 36.2 (2002), p. 435. 
vida. Prieto distingue la "Beatus ille" imaginada por el lector Minaya de la Beatus ille imaginada por el lector extratextual. En esta dinámica de fijar distintas novelas de una misma obra, quizá habría que añadir otras dos formas de Beatus ille: la novela imaginada por Jacinto Solana, que no llegó nunca a existir, y la novela real e imaginada por el autor real, Antonio Muñoz Molina, que, aunque probablemente no coincida con ninguna de las otras tres, es la única palpable.

Aunque la obra nos llega, supuestamente, de manos de la recreación o creación primera de Minaya, hay que ser conscientes de la incapacidad intelectual del personaje. De los personajes de la novela, es él quien estaba menos preparado para hablar sobre Solana: en parte porque, debido a su juventud, no podía conocer lo que ocurrió en el tiempo de Mariana, Solana y su tío Manuel; y en parte, porque sufre una enfermedad que suele atacar a los personajes del ubetense: la confusión de la realidad y de la ficción. Minaya es el más entusiasta de los lectores ficticios de la vida de Solana. Sin embargo, y esto responde a la concepción literaria de Muñoz Molina, ese entusiasmo no es suficiente para ser un buen lector. El buen lector, para el ubetense, es el que ha aprendido a leer en la buena literatura, que es aquella que lo previene a uno contra la ficción, no se deja llevar por los tópicos literarios, sino que juzga lúcidamente esos tópicos aprendidos e intenta tener una visión más nítida de la realidad, usando las herramientas de inteligencia y claridad que le proporciona la literatura.

El empacho de ficción y el exceso de imaginación que padece el lector ficticio, Minaya, es recriminado al final de la novela por el propio Jacinto Solana: "Era usted quien exigía un crimen que se pareciera a los de la literatura y un escritor desconocido o injustamente olvidado que tuviera el prestigio de la persecución política y de la obra memorable y maldita, condenada, dispersa, exhumada por usted al cabo de veinte años" ${ }^{12}$. Minaya se ha equivocado al leer, ha rastreado las pistas y se ha quedado con las que se adaptaban a sus expectativas. Como el propio Solana le dice, él le ha ofrecido lo que quería encontrar, y por eso, precisamente, lo ha encontrado. Herzberger, en este sentido, sostiene que había muchas posibles historias y que la imaginada por Minaya era sólo una entre muchas. Ni a Minaya lo salva la lectura, ni a Solana la escritura:

Yet Beatus Ille is not a novel that ultimately opts to authenticate life either through narration or as narration. Indeed, both Solana and Minaya are unable to define or legitimate themselves through writing and reading, for each knows (as does Muñoz Molina) that their narrative is only one story among

${ }^{12}$ A. Muñoz Molina, Beatus ille, Barcelona, Seix Barral, 2002, p. 309. En adelante se citará en el texto, entre paréntesis, por esta edición. 
many, that all stories are illusions, and that illusions ultimately leave the characters unpropped against life ${ }^{13}$.

Aunque Herzberger, y el propio Solana, sostiene que existían muchas historias posibles, sólo hay una que responde a la realidad: aquélla que cuenta la traición de Solana ante su amigo Manuel y ante los ideales de la república, y la del Solana fracasado, incapaz de escribir la gran obra literaria que anhelaba. Por eso, es verdad que la escritura no salva a Solana y que la lectura tampoco salva a Minaya: porque el primero ha ideado una historia que sólo se aproxima levemente a la realidad; y porque el segundo no ha sido capaz de discernir aquello que había de realidad, y aquello que había de ficción, en los manuscritos que encontró y en las historias que oyó en casa de su tío Manuel. Por eso la lectura de Minaya es un fracaso y por eso, aunque haya muchas historias posibles, sólo una convierte al lector en un buen lector (en este caso un buen lector-detective) y al escritor en un buen escritor. Efectivamente, de este planteamiento bebe la concepción literaria de Muñoz Molina, para quien la literatura tiene que ser un esfuerzo continuo no sólo por entretener -que también- sino por dilucidar los entresijos de la realidad y desechar los mitos de la literatura. El escritor no debe darle al lector los tópicos a los que está acostumbrado (según el horizonte de expectativas conceptuado por Jauss ${ }^{14}$ ), sino zarandearlo en esos tópicos y hacerlo consciente de las verdades de la realidad. Por otra parte, el lector no tiene que buscar las historias que lo engañen, en las que se acomoda su inteligencia, sino que debe exigirle al escritor que haga un esfuerzo de lucidez y que lo lleve consigo.

Los esfuerzos del escritor y del lector deben dirigirse en una misma dirección, porque sólo de esa forma se puede llegar a completar la creación de una obra literaria. El propio Herzberger, al comienzo del artículo citado, señala que en la novela se explora "the way in which writing and reading coalesce as both prefigurative and configurative components of narrative creation" 15 . Efectivamente, el escritor es el primer paso en el proceso comunicativo (prefiguración) y el lector, el segundo paso, configurador de un significado concreto para la obra. En el caso de Beatus ille el lector ficticio camina hacia el mismo punto que el autor ficticio, pero con el inconveniente que se ha visto antes: la dirección equivocada hacia la que ambos se encaminan.

${ }^{13}$ D. K. Herzberger, art. cit., p. 389.

${ }^{14} \mathrm{Vid}$. H. R. Jauss, "El lector como instancia de una nueva historia de la literatura", en J. A. Mayoral (comp.), op. cit., p. 77.

${ }^{15}$ D. K. Herzberger, art. cit., p. 382. 
Para algunos escritores, Minaya es, tal vez, lo que ellos considerarían un lector modelo: obedece y experimenta exactamente lo que Solana dispone. No obstante, éste no es el lector modelo, extratextual, al que Muñoz Molina dirige sus obras. Minaya experimenta unos sentimientos según los prejuicios que tenía acerca de Solana y de su historia. A Minaya no lo ha cambiado la literatura, al contrario, la literatura se ha adaptado a sus expectativas. Quien sí recibe una modificación en su forma de enfrentarse a la ficción, quien sí se da cuenta de que hay que estar alerta contra las trampas de la imaginación es el lector real de Muñoz Molina, que se percata, cuando Minaya se encuentra con Jacinto Solana, de que hay una gran mentira detrás de toda esa historia de heroicidades y grandezas artísticas, tramada por el propio Solana y actualizada por Minaya. Minaya no es el lector modelo del ubetense; su lector modelo es el que comprende el proceso de desmitificación que se está dando en la novela. El ubetense renuncia a ofrecerle al lector lo que está esperando. Solana ofrece a Minaya el pacto para seguir inmersos en la mentira; Muñoz Molina se niega a ese pacto de silencio y le muestra la verdad a su lector real, no permite que Solana silencie lo que en realidad fue la historia de su vida:

Piense, si lo prefiere, que este momento no existe, que usted no me vio esta tarde en el cementerio o que no fui más que un viejo tullido que miraba una tumba y al que usted vio y olvidó como un rostro que se le cruzara en la calle. Ahora usted es el dueño del libro y yo soy su personaje, Minaya. También yo lo he obedecido ${ }^{16}$ (Beatus ille, p. 310).

El caso de Santiago Biralbo no es exactamente igual que el de Minaya. Piénsese que Beatus ille, según suele considerarse, es una metanovela donde, forzosamente, son más patentes las relaciones entre escritor, escritura y lector dentro del propio texto. En El invierno en Lisboa ocurre algo singular. El narrador que se comunica con el lector real es el innominado amigo de Biralbo, que es, a la vez, el lector ficticio que escucha la historia contada por el pianista. De la misma forma, el músico es, además de contador de su propia historia, el lector ficticio que debe desentrañar las incógnitas planteadas en el caso de la desaparición de Lucrecia y del cuadro de Cézanne, ambicionado por Toussaints Morton, Daphne y Malcolm, convirtiéndose, de esta manera, en lector-detective. Existe entonces en esta novela un doble proceso de lectura: la pasiva, llevada a cabo por el narrador, que reconstruye la historia para poder transmitírsela al lector real; y la lectura activa de una serie de pistas y engaños a los que se

\footnotetext{
${ }^{16}$ Esto apoya, precisamente, que Minaya escribe la novela que Solana no pudo concluir.
} 
enfrenta Biralbo, que, como el narrador, se convierte en transmisor de una historia, en este caso, ante su amigo innominado.

Acerca del proceso de lectura llevado a cabo por el que después se convertirá en el narrador principal de la historia, afirma Rich que, "as an author, the narrator «writes» Biralbo's story, but he must first «read» it, which he does by supplanting its indeterminacies" ${ }^{17}$. Como se puede apreciar, el narrador actúa de la misma forma que un lector real. El lector real se introduce en la historia que le cuentan, ya sea escrita u oral, y trata de rellenar con ayuda de su inteligencia los datos que no quedan claros en la narración, las indeterminaciones, voluntarias o no, con las que el narrador ha sembrado su texto. En este sentido, son interesantes las palabras de Forster, para quien "el misterio es esencial para la trama, y no puede apreciarse sin inteligencia [...]. Para apreciar un misterio, parte de la mente debe dejarse atrás, rumiando, mientras la otra parte sigue avanzando". Un poco después, insiste en que "la memoria y la inteligencia están íntimamente conectadas, pues si no recordamos no podemos comprender [...]. El que teje la trama espera que recordemos, y nosotros esperamos que no nos deje cabos sueltos" ${ }^{18}$. Efectivamente esos son los papeles de lector y autor: el primero tiene que ser lo suficientemente paciente para esperar a que las lagunas vayan llenándose de significado y ha de establecer hipótesis temporales que le permitan continuar la lectura. El recuerdo de esas hipótesis hace que, después, el autor las desmienta o las confirme, dependiendo de sus intenciones. Lo fundamental es que el autor recoja, en el desenlace de la novela, el fruto de esos vacíos, que fueron sembrados a lo largo de la obra. Ciertamente, como ha dicho Forster, hay un contrato latente entre lector y autor en el que el primero se compromete a permanecer atento, a hacer uso de su inteligencia y memoria; y en el que el segundo se compromete a desenmascarar los misterios de la trama, para que el esfuerzo del lector no haya sido inútil.

El lector real tiene como único informante, para conocer los detalles de la historia, al narrador que se la cuenta. A partir de la ruptura que se produjo a principios de siglo XX con el narrador omnisciente y seguro, propio de la novela decimonónica, el lector no tiene otra opción que confiar en un narrador inseguro, al que se le escapan aspectos importantes de la historia que el lector debe suponer o imaginar. A este respecto, Oropesa destaca, en relación con el narrador de Beatus ille y de El invierno en Lisboa, la importancia del ejercicio

\footnotetext{
${ }^{17}$ L. Rich, op. cit., p. 71.

${ }^{18}$ E. M. Forster, Aspectos de la novela, Xalapa (México), Universidad Veracruzana, 1961, p. 116.
} 
creativo del lector extratextual: en la primera, porque "el reto intelectual es descubrir quien es el narrador"; en la segunda, porque "hay que sacar el máximo provecho de la información que se posee y ser capaz de sacar conclusiones, porque el lector no sabe en qué ocasión el narrador le va a fallar" ${ }^{19}$.

Este mismo problema es el que se encuentra Biralbo en su recorrido por los infiernos de la noche y de la delincuencia. Sus informantes son realmente parciales, subjetivos y le cuentan, descaradamente, lo que les conviene para sus propósitos. Si a Minaya, recuérdese, se le cuenta la historia que esperaba, Biralbo se encuentra ante una historia que lo desborda y lo desubica por completo: él espera que Lucrecia viaje para reunirse con él y se encuentra, sin saber por qué, con que Lucrecia se marcha sola hacia Lisboa. Cuando esperaba cartas que hablaran de ellos y de la distancia que los separaba, se encuentra con una carta en blanco, o con un plano de no sabe dónde. Ignoraba que Lucrecia estaba usando el poder que había adquirido sobre él, en virtud de un amor que no sería correspondido hasta el final: Lucrecia sabía que el pianista guardaba absolutamente todas sus cartas. Biralbo tampoco conoce la causa por la que los villanos lo persiguen y lo torturan pidiéndole el cuadro, el dinero o el paradero de Lucrecia. Todos estos indicios de que algo raro sucede empujan a Biralbo a actuar, a buscar Burma en Lisboa, a buscar a Lucrecia y a exigirle que le cuente absolutamente todo lo que ignora. Biralbo se ha convertido, indirectamente y a través de su amigo narrador, en el apoyo del lector real para desentrañar la misteriosa búsqueda de los villanos y los extraños viajes de Lucrecia.

El lector ficticio que es Biralbo sufre durante toda la novela una desorientación absoluta. Sin embargo, actúa con inteligencia, va recabando datos de las frases a media de los malhechores, de los gestos extraños de Lucrecia y de sus palabras que no comportan un significado claro. Los únicos informantes fiables de Biralbo son sus amigos: el narrador sin nombre, Floro Bloom o Billy Swann. Incluso ellos, en algún momento y en pro de su bienestar, engañan al pianista. Billy Swann es, en este sentido, determinante, porque será él quien le dé la carta de Lucrecia, después de llevarla muchos meses consigo y quien finalmente desvele el lugar de Lisboa en que vive la protagonista.

El otro lector ficticio de la obra, el narrador, escucha la historia directamente de boca de Biralbo, al menos los últimos años de la historia, durante los cuales había perdido el contacto con el pianista y con sus líos de falda. Al principio de la novela, el narrador también conoce los hechos de primera mano, participa,

${ }^{19}$ S. A. Oropesa, La novelistica de Antonio Munoz Molina: sociedad civil y literatura lúdica, Jaén, Universidad de Jaén, 1999, p. 58. 
incluso, en la acción, ya que tuvo un negocio con Malcolm. Tendrá que esperar, no obstante, a que Santiago Biralbo le desvele algunos de los misterios que él no llegaba a comprender: por ejemplo, aquella vez en que el narrador y Floro Bloom encontraron restos de ceniza y cigarrillos en el Lady Bird y supusieron que había sido él y Lucrecia. Tiempo después conocerá, de boca de Biralbo, los pormenores de aquella noche. El narrador también se percató de las miradas que Lucrecia dirigía al pianista, pero no sabrá si aquellas insinuaciones significaban algo hasta que Biralbo desvele su historia de amor. Se podría decir que se cumple aquí aquello de que las apariencias engañan y de que la literatura, en este caso el relato oral de Biralbo, arroja luz sobre las incógnitas de la realidad.

Santiago Biralbo, por tanto, es lector y transmisor de la historia. Gracias a sus indagaciones ha conseguido descubrir las intrigas que Lucrecia, Malcolm y sus secuaces se traían entre manos. Y después de conseguirlo ha transmitido la historia al lector real. El lector real por su parte, en manos del narrador sin nombre, tiene que hacer un acto de imaginación al final de la novela. Los espacios vacíos con los que se encuentra en el desarrollo de la obra son rellenados, con éxito, por el narrador, informado por Biralbo. Sin embargo, cuando el pianista desaparece de la acción y aparece Lucrecia buscándolo, el lector real sólo posee las informaciones parciales del narrador, que también desconoce dónde está Biralbo, qué hace allí Lucrecia y por qué lo busca, y, en última instancia, cómo va a acabar la historia de amor entre los dos. El lector real, y el narrador que también es lector ficticio, tiene que hacer un esfuerzo imaginativo para intentar poner un cierto orden a ese final abierto de la novela. Obviamente, nadie sabe qué sucede después, envuelto todo, como está, en el halo enigmático del pianista y de su amante. El único que podría informar a los lectores del futuro es el propio Biralbo que, convertido ya en Giacomo Dolphin, se ha callado definitivamente. Son irónicas las palabras del recepcionista que informa al narrador de que el músico se ha marchado: “- ¿Le dijo algo más? / Usted conoce al señor Dolphin. -El recepcionista sonrió, ligeramente erguido-. No es hombre de muchas palabras" ${ }^{20}$. Aquí se apaga para siempre la voz de Biralbo.

Darman es el último de los lectores ficticios que actúan, haciendo suya la historia que le cuentan o que rastrea. Puede parecer extraño que se hable de Darman, el narrador sin discusión de Beltenebros, como un lector dentro de la obra. Parece que va en contra de esta cualidad de receptor intelectual que sea él quien lleva, siempre, la voz cantante en la novela, quien decide lo que debe

${ }^{20}$ A. Muñoz Molina, El invierno en Lisboa, Barcelona, Seix Barral, 2003, p. 219. 
hacerse, quien determina caprichosamente ciertos aspectos de su aventura, aunque esté bajo las órdenes de un grupo de resistencia clandestino. Estas objeciones se desvanecen cuando se tienen en cuenta los argumentos que apoyan el carácter de lector-detective de Darman. En primer lugar, para localizar a Andrade, y acabar con él, el protagonista debe dilucidar la validez de ciertas pistas que encuentra durante su búsqueda. De la misma forma, va oyendo lo que diversos informantes le cuentan: desde el personaje deforme, que es portero de la boîte, hasta la conversación que escucha, entre Ugarte y sus acompañantes, en el almacén abandonado en que esperaba hallar a Andrade. En segundo lugar, Darman es capaz de amarrar los cabos sueltos que existieron, veinte años antes, en el caso Walter. Como un lector real, mantuvo en su memoria todas las imprecisiones del caso Walter y, por efecto del estilo especular de la obra, se percata de las similitudes que guardan ambos casos. A partir de ese momento, Darman es capaz de rellenar las lagunas existentes, con una sagaz inteligencia, y llegar a una conclusión. En el sentido enunciado, Darman es un lector-detective.

Por otra parte, Darman es un lector en el sentido literal, un lector de novelas. Rebeca Osorio, madre, antes de que se produjera el ajusticiamiento de Walter, era la encargada de transmitir consignas a los miembros del grupo de resistencia a través de sus obras. Darman las había leído todas y, de la misma forma que el resto de los integrantes del grupo, había seguido las instrucciones que allí se indicaban. Silvia Bermúdez, en su artículo "Negro que te quiero rosa: la feminización de la novela de espías en Beltenebros", pone en relación estos dos géneros: el negro y el rosa. En su estudio, sostiene la existencia de un cambio de papeles en cuanto a la sexualidad, con la que se relaciona cada uno de los géneros. Si el género negro, tradicionalmente, está asociado con el sexo masculino y el género rosa con el sexo femenino, en Beltenebros se ha producido una confluencia de ambos: el género rosa se convierte en la guía que deben seguir los hombres duros de la novela, incapaces de actuar sin las órdenes inscritas dentro de las novelas que Rebeca Osorio escribía; por otra parte, el sexo femenino actúa según los patrones básicos y los tópicos conocidos de la novela negra. De hecho, es Rebeca Osorio, hija, quien, en última instancia, acaba con el comisario Ugarte: el sexo femenino, según Bermúdez, se ha apoderado del ámbito cerrado, y exclusivo del sexo masculino, que suponía el género negro. Muñoz Molina, al convertir a Darman en lector de novela rosa ha roto las barreras que separaban estos dos géneros populares, ligados, cada uno de ellos, a uno de los dos sexos ${ }^{21}$.

${ }^{21}$ Vid. S. Bermúdez, "Negro que te quiero rosa: La feminización de la novela de espías en Beltenebros”, España Contemporánea, VII.2 (1994), pp. 7-25. 
Darman, en otro sentido, y al igual que Biralbo o Minaya, experimenta un sentimiento continuo de inseguridad. Durante el primer caso, no hacía más que cumplir los mandatos de la organización antifranquista, sin detenerse, como haría todo buen lector real, en los espacios vacíos que tenían lugar en la historia. En el caso Andrade, por el contrario, Darman se interesa por los dilemas irresolutos, y las contradicciones de la historia, y pretende otorgarles, con sus indagaciones, una conclusión razonable y cierta. El problema es que se produce el conocimiento de la verdad demasiado tarde, cuando ya Walter y Andrade han sido ejecutados. En esta actuación de Darman, puede apreciarse un comportamiento idéntico al de cualquier lector extratextual. El lector real reacciona como Darman, o Darman actúa como el lector real, ante los misterios de la historia: determina hipótesis, rastrea pistas a lo largo del texto, desconfía de informantes inseguros y, finalmente, asiste y participa en la resolución de ese misterio. Ivette Sánchez habla acerca del papel del lector real ante el suspense de una novela. Sus palabras son perfectamente aplicables al lector implícito de las tres primeras novelas de Muñoz Molina:

El lector o espectador reacciona participando comprometida y emocionalmente en la espera de algo inesperado, entregándose con placer a este particular código comunicativo hecho de un juego de incertidumbres, sorpresas, despistes, engaños, que desemboca en el deseo de resolverlo todo ${ }^{22}$.

Este fragmento describe perfectamente la actitud de Darman ante el caso del último de los traidores, excepto en el sentido placentero de la lectura: para el lector real ese enfrentamiento con el misterio puede convertirse en un juego de inteligencia; para Darman, responde a una exigencia vital, a la necesidad de tranquilizar la propia conciencia ante las injusticias cometidas en el pasado, y de asegurarse que no está cometiendo las mismas atrocidades en el presente ${ }^{23}$. La lectura de Darman se lleva a cabo para intentar descubrir por fin qué persona se oculta bajo el nombre de "Beltenebros" y evitar, así, nuevas injusticias y asesinatos.

${ }^{22}$ I. Sánchez, "Recursos de suspense en las novelas de Antonio Muñoz Molina", en I. Andrés-Suárez (ed.), Ética y estética de Antonio Muñoz Molina, número monográfico de Cuadernos de narrativa, 2 (1997), p. 93.

${ }^{23} \mathrm{La}$ diferencia de actitudes se corresponde con el cambio de perspectiva que se produce, según J. F. Colmeiro, en la transformación de la novela policíaca -que responde a un planteamiento estético- en la novela negra -que implica un comportamiento y una postura ética- (Vid. José F. Colmeiro, La novela policíaca española. Teoría e historia crítica, Barcelona, Anthropos, 1994, p. 61 y ss.). 
El segundo tipo de lector ficticio, que puede encontrarse en la obra del ubetense, es el de aquellos personajes que son receptores de una historia, pero que no actúan como detectives, sino simplemente escuchan aquello que otro les está narrando. Muñoz Molina ha confesado que sus personajes le importan más por lo que cuentan, o por lo que están dispuestos a contar, que por lo que hacen ${ }^{24}$. Este interés particular del escritor provoca que, en la mayoría de sus novelas, haya personajes que cuentan cosas y personajes que las escuchan. De hecho, muchas de sus obras están estructuradas, precisamente, de esta manera: piénsese en Carlota Fainberg, que es el ejemplo más flagrante de transmisión y recepción de una historia dentro de la propia novela; o en la parodia folletinesca Los misterios de Madrid, donde Lorencito Quesada narra sus aventuras madrileñas a un mozo farmacéutico que lo idolatra y que será el encargado de redactar la obra; o en El jinete polaco, donde Nadia escucha atentamente todas las voces de Mágina, recuperadas por su amante Manuel y transmitidas de manera detallada.

Siguiendo un criterio estrictamente cronológico, se comenzará por el análisis de El jinete polaco. Se ha hablado antes de la interpretación que hace Rich de Manuel como lector inscrito o implicado dentro de la novela. Se sostenía allí que más que lector inscrito, Manuel era el verdadero emisor de la historia y, por tanto, era Nadia, en realidad, la receptora. Efectivamente, Manuel fue el receptor de todos aquellos cuentos que contaba su abuelo al calor de la lumbre en las noches de invierno, o de aquellas leyendas que los hombres de campo se contaban antes de marchar a la recolección de la aceituna. Además de esas historias que hablaban del comandante Galaz, del médico don Mercurio o de la momia emparedada, Manuel fue también el receptor de una serie de costumbres y de tradiciones orales que marcaron toda su infancia: los miedos irracionales a ciertos poderes maléficos de la naturaleza (por ejemplo, la muerte súbita para quien, en una noche de San Juan contara todas las estrellas del cielo; o el miedo extravagante a morir de un resfriado o asfixiado por los gases virulentos e incontrolables del brasero), el sentimiento de pertenencia a una familia y la necesidad de conservar y transmitir sus costumbres propias.

Ciertamente, Manuel es en su infancia únicamente receptor, pero después se convertirá en el transmisor efectivo de la herencia recibida en su niñez, y contra la que se había rebelado en la adolescencia. En ese momento, el lector ficticio es Nadia. Manuel ha sido movido por todas las narraciones que recibió de pequeño

${ }^{24}$ A. Muñoz Molina, "La invención del personaje”, en M. Mayoral (coord.), El personaje novelesco, Madrid, Ministerio de Cultura-Cátedra, 1993, p. 87. 
-primero en forma de rebelión y luego en forma de aportación personal a la historia colectiva de su familia-. En cierta forma, también Manuel actúa como lector-detective al interesarse por el desenlace de la leyenda de la emparedada. No puede compararse, sin embargo, con Minaya, Biralbo o Darman. Estos se toman el misterio que hay que resolver como algo personal; Manuel, en cambio, encuentra casi por casualidad la resolución del caso. No se preocupa por él, llega a Mágina no movido por el deseo de conocer el final de la historia -se conformaba, como cuando era pequeño, con los detalles legendarios que le habían contado-, sino con motivo de la muerte de su abuela Leonor. La actividad de Manuel se refiere, precisamente, al hecho de haberse convertido en uno más de los eslabones en la transmisión de la historia familiar. En este sentido, Manuel está a mitad de camino entre los lectores-detectives, de las primeras novelas del ubetense, y los lectores que no participan en la elucidación de la historia que les están contando.

Nadia, en cambio, es la receptora total de la historia de Manuel. Es verdad que, en ciertas contadas ocasiones, Nadia toma la palabra y cuenta a Manuel -y de esto se beneficia el lector real- algunos episodios oscuros de su vida. A pesar de ello, la historia fundamental es la que cuenta Manuel y la lectora ficticia es Nadia, durante, prácticamente, la totalidad de la novela. Nadia se convierte en el lector paciente que espera a que Manuel le vaya contado su vida, las relaciones infantiles con su familia, los problemas amorosos y su enfado universal durante su adolescencia y, ahora, la reconciliación con sus raíces. Nadia se comporta, también, como un lector real: ante las lagunas que Manuel deja en su narración, por despiste o por incapacidad, ella interpone su propia experiencia vital para completar esas imprecisiones. De manera que, cuando Manuel no puede contarle lo que pasó cierta noche, Nadia acude en su ayuda y transpone sus experiencias vitales a la historia ${ }^{25}$ : durante aquella noche de borrachera acerca de la cual Manuel no recuerda nada, Nadia, que estuvo con él, aporta esas informaciones necesarias, completa esos vacíos como un lector activo y permite, así, que la historia narrada pueda continuar desarrollándose. El lector real debe apoyarse en

${ }^{25}$ Bobes Naves habla acerca de esta transposición de experiencias vitales en el texto literario que se está leyendo. Ella se refiere, concretamente, a los personajes, pero es extensible a todos los aspectos de la novela: "Una galería de hombres, a los que conoce el novelista [...] da paso, por copia directa o por selección y combinación, a un personaje ficcional. El lector, partiendo también de la galería de personas que conoce, va identificando por su parte rasgos sueltos o personajes completos que se corresponden con su experiencia vital" (M. C. Bobes Naves, "El personaje novelesco: cómo es, cómo se construye”, en M. Mayoral, op. cit., pp. 45-46). 
los datos sacados a la luz por ambos personajes para componer, para "crear" el significado global de la obra.

El proceso de la narración de Manuel, por tanto, antes de llegar al lector real, pasa por las relevantes contribuciones que aporta Nadia, quien rellena algunas de los espacios vacíos que se dan en lo que cuenta Manuel, como se ha visto. Marco Kunz, en una reflexión acerca de las relaciones entre el lector real y el narrador de El jinete polaco, omite un paso bastante importante: el de la recepción de Nadia como lector ficticio. Él compara las técnicas utilizadas por Manuel, para elaborar su historia, con las técnicas similares que debe utilizar el lector real en la recepción de la novela:

En El jinete polaco la técnica de anticipación y resonancia no está simplemente al servicio de una representación mimética del trabajo de la memoria del protagonista, sino que además obliga al lector a una actividad mental paralela a la de Manuel, es decir, establece una analogía entre las anacronías, vacilaciones y repeticiones de la narración y el proceso de la recepción ${ }^{26}$.

Todos esos grandes esfuerzos memorísticos, llevados a cabo por Manuel, tienen, no obstante, el apoyo de la memoria personal de Nadia, que en su corta estancia en Mágina, también conoció algunas de las leyendas propias de la tradición colectiva. Cuando Manuel se acuerda de la leyenda del comandante Galaz, Nadia le señala ciertos aspectos de su vida cotidiana, independientes del mito, que sólo la hija podía conocer. Así, esos esfuerzos de anticipación y de resonancia a los que se refiere Kunz, y que efectivamente existen en la obra, están enriquecidos por las aportaciones puntuales y certeras de Nadia. Después de este enriquecimiento, la obra llega al lector real, al último receptor de la narración que, siguiendo el mismo proceso llevado a cabo por Manuel, es capaz de atribuir un significado completo a lo que está leyendo. Por todo lo dicho, el paso omitido en esta reflexión de Kunz debe ser tenido en cuenta en el momento de la recepción final, porque el lector real sería incapaz de entender algunos aspectos indescifrables de la trama sin la ayuda de la hija del comandante Galaz.

En otro sentido, el lector extratextual establece una relación sentimental con los protagonistas de la novela que lo impele a seguir oyendo las historias que Manuel le está contando. Sin embargo, en algunas ocasiones el lector real no puede mandar sobre los personajes ni encuentra el apoyo de Nadia. Casi al final de la obra, cuando existe una ligazón sentimental con alguno de los personajes de las historias del narrador, como, por ejemplo, el teniente Chamorro, ocurre algo

${ }^{26}$ M. Kunz, “Anticipación y resonancia en El jinete polaco”, en I. Andrés-Suárez (ed.), op. cit., p. 137. 
que despierta el deseo de que sigan contando. Manuel se pasea, inopinadamente, por las calles de Mágina. En ese paseo se encuentra con Chamorro y lo describe del siguiente modo: "Pasa a mi lado sin verme, gesticulando con un dedo acusador mientras habla de la corrupción de los tiempos, y un acceso de timidez me impide acercarme a él, aunque me ha contado mi padre que siempre le pregunta por mí" ${ }^{27}$. El lector real se queda con ganas de saber qué le habría contado el teniente en el caso de que la timidez de Manuel le hubiera permitido saludarlo; espera que Manuel se arrepienta en el último momento y le hable y le pregunte cómo está, y se deje contar historias como las de su infancia; desea que el teniente Chamorro reconozca al forastero, en que se ha convertido Manuel, y finalmente mantenga con él una conversación. Esto, sin embargo, no ocurre. Manuel y el teniente Chamorro siguen sus caminos, y Nadia no puede completar la información porque no está, porque todavía no ha llegado de Nueva York.

La última parte de la novela abre nuevas perspectivas de historias futuras. Mientras Manuel se establece en su pasado, está pensando las cosas que tiene que contarle a Nadia. Y se las va contando, aunque ella no esté presente. Gracias a esas ansias de Manuel por contarle a su amante -al lector ficticio que es Nadiatodos sus sentimientos y todas sus impresiones, el lector real tiene acceso a ese material de la historia. Por esta razón es tan importante la función de Nadia. El monólogo de Manuel no llegaría hasta el lector si no existiera la figura de la amante. Es más, sin la hija del comandante Galaz, Manuel no habría salido jamás de la dinámica de las traducciones sin sentido y de la transmisión de palabras que no lo explicaban íntimamente. Hasta que no aparece Nadia en su vida, Manuel no se convierte en creador de historias. Con su llegada, Manuel retoma las palabras de su infancia y de su ciudad natal, las palabras de Mágina y de sus gentes, que consiguen introducirlo de nuevo en una historia colectiva que le permite abandonar el desarraigo y la desorientación en la que se encuentra.

El pobre Lorencito Quesada, protagonista de Los misterios de Madrid, sufre en sus carnes una desorientación tan intensa como la de Manuel, aunque, por supuesto, mucho menos heroica. Las aventuras que le acontecen en Madrid están teñidas por el humor y la parodia. Nadie, en su sano juicio, creería dignas de ser contadas esas aventuras, pero Lorencito Quesada, el ilustre reportero de Mágina, se cree en el deber de contarle al farmacéutico sus desdichas y las de una familia destacada de la ciudad. Peor juicio tiene todavía el farmacéutico que no sólo considera que esa aventura es digna de ser escuchada por él, sino que es digna de ser escuchada por todo el público lector.

${ }^{27}$ A. Muñoz Molina, El Jinete polaco, Barcelona, Seix Barral, 2002, p. 577. 
El farmacéutico es el verdadero lector ficticio de esta obra. Lorencito Quesada tiene que ir por las calles de Madrid buscando pistas que le indiquen dónde se encuentra y quién robó el Santo Cristo de la Greña. En este sentido, como el resto de los lectores-detectives de los que se ha hablado, participa de la cualidad de lector dentro de la obra. La diferencia de Lorencito con el resto de los personajes incluidos en esta categoría es que aquellos, efectivamente, son capaces de interpretar las pistas y de sacar alguna conclusión, mientras que él está completamente entregado a lo que los malhechores, que le han tendido la trampa, quieran hacerle creer. El joven Quesada es tan inocente y tan crédulo que es incapaz de engarzar ningún tipo de historia, que se acerque a la verdad, ni de sacar ninguna conclusión que arroje luz al caso. Por esto, Lorencito no hace más que dejarse llevar hasta que el caso se soluciona por sí solo. Él no aporta nada en absoluto a la resolución del caso. Otra cosa es que, por culpa de sus problemas con el establecimiento del límite entre la realidad y la ficción, crea que es indispensable para la aclaración de los misterios. Sólo se asiste a una cierta rebelión del reportero al final de la obra, cuando parece tomar las riendas de su aventura: "Un momento, señor conde [...] que yo también tengo que decirle unas palabras, aunque no sean en francés" ${ }^{28}$. El pobre Lorencito cree haberse percatado de la solución del caso cuando ha sido Olga, la bailaora psicóloga, la que lo ha arrastrado a descubrirlo, la que se lo ha puesto, prácticamente, delante de sus ojos:

Ahora lo veo todo claro -dijo Lorencito: el labio superior volvía a temblarle-. Usted estaba conchabado con los ladrones. Usted tuvo la idea de enredarnos al pobre Matías Antequera, que en paz descanse, y a mí, para que nos tomaran por culpables del robo. Si no, ¿por qué sabían que yo paraba en la pensión del señor Rojo? (Los misterios de Madrid, p. 177).

El verdadero lector ficticio de la obra es, sin embargo, el farmacéutico que escucha atentamente la historia que Quesada le cuenta. Como Lorencito, el mancebo está enfermo de literatura y de imaginaciones ${ }^{29}$. Esto es lo que lo obliga a seguir las indicaciones expresas del periodista. El joven farmacéutico se define de la siguiente forma:

Trabajo de mancebo en la farmacia Mataró, pero mi verdadera vocación es la literatura, y dentro de ella, el periodismo. Ya sé que el mío es un sueño

${ }^{28}$ A. Muñoz Molina, Los misterios de Madrid, Barcelona, Seix Barral, 2002, p. 177. En adelante se citará en el texto, entre paréntesis, por esta edición.

${ }^{29}$ Vid. J. M. Begines Hormigo, "La locura de Don Quijote en algunos personajes de Antonio Muñoz Molina”, en E. Torre (ed.), Medicina y Literatura V, Sevilla, Padilla Libros, 2006, pp. 133-149. 
inalcanzable, pero cada vez que abro las páginas de Singladura y veo en ellas un artículo, una interviú o un reportaje firmado por Lorencito Quesada, cada vez que sintonizo Radio Mágina y escucho su bien timbrada voz, doy en imaginar que alguna vez yo podría ser como él, que las cosas que escribo, robándole horas al sueño, se publicarán un día (Los misterios de Madrid, p. 183).

Al final de la obra hace su aparición y trastorna toda la estructura de la novela. Lorencito Quesada no está contándole al lector real sus aventuras; es el mancebo de la farmacia Mataró quien empujado por no se sabe qué se decide a transcribir y a comunicar públicamente lo que tan en secreto le fue confesado una mañana de Jueves Santo:

«Lo que voy a contarle [...] será siempre un secreto entre nosotros, a no ser que a mí me ocurra algo. Es posible que mi vida esté en peligro. Sé demasiadas cosas, y aunque he jurado por mi fe de católico no divulgarlas, puede que algún día dejen de confiar en mí y decidan eliminarme... Por favor, no me interrumpa mientras hablo. Usted guardará la grabación de mis palabras, y para mayor seguridad no estaría mal que las transcribiera en sus ratos libres. Sólo si yo desaparezco de repente, o si muero en extrañas circunstancias, estará usted autorizado a difundir el contenido de las cintas. Júremelo, o prométamelo» (Los misterios de Madrid, p. 184).

Según estas palabras, y si el farmacéutico mantiene su adoración por la persona de Quesada, para que esta historia le haya llegado al lector extratextual, por medio del mancebo, el periodista o bien ha desaparecido o bien ha muerto. Lo segundo no parece probable, visto que Muñoz Molina, en alguna ocasión, habla de él sin tener conciencia de haberlo matado ${ }^{30}$. Tal vez, pero esto forma parte de las conjeturas del lector real para intentar subsanar las imprecisiones, haya sido raptado por sus enemigos (cosa improbable, porque Lorencito no tiene capacidad intelectual para dañar a nadie), o que se haya alejado, continuando con su línea de actuar como en la literatura, para protegerse de unos adversarios, si es que existen, que no lo toman en consideración.

Parece más verosímil que el farmacéutico, intentando conseguir la fama literaria que le había sido negada o intentando elevar a su ídolo a lo más alto del panorama de las letras españolas, haya publicado sus memorias, en un acto de egoísmo o en un acto desinteresado de generosidad. Nuevamente se halla, en la obra de Muñoz Molina, un personaje cuyo papel fundamental es el de oír la

30 "Muchas veces me gustaría, no sé, hacer otra aventura suya. Claro, ya tendría que trabajar en la televisión local o algo. Es muy cervantino, ¿verdad?, el pobre" (J. M. Begines Hormigo, "Conversaciones con Muñoz Molina", Philologia Hispalensis, 18 (2004), p. 17). 
historia que alguien le está contando y que, finalmente, se convierte en una pieza indispensable para el desarrollo argumental de la novela. Sin la existencia del farmacéutico innominado, el lector extratextual no habría conocido la aventura del intrépido periodista. Por otra parte, el mancebo de farmacia, que pertenece al grupo de los que se han llamado lectores ficticios pasivos, lleva a cabo una actividad interesantísima y de gran trascendencia: la transcripción de la historia, narrada oralmente por Lorencito y grabada en el casete, y la publicación de esa transcripción. De esta forma, la pasividad sería sólo en comparación con la actividad física de los lectores-detectives, porque, por otro lado, no es un mero receptor de lo que escucha, sino que participa en la elaboración de la novela de distintas formas, pero casi siempre, y la más importante, comentando lo que Lorencito Quesada le cuenta o lo que deja de contarle:

Es inútil rogarle que cuente con detalle lo que sucedió después: su caballerosa discreción, acrisolada en el ejercicio del secreto profesional, que es el primer mandamiento del periodismo, en este punto se vuelve inconmovible. En su cara llena, habitualmente muy seria, sobre todo desde que volvió de Madrid, se le dibuja una sonrisa, y su mirada, a un tiempo risueña y melancólica, se pierde en el infinito, o en el fondo de la copa de vino quinado que sigue tomando con puntualidad cada noche a las nueve. [...] Sólo cuenta que se durmió muy tarde, que Olga no quería apagar la luz (Los misterios de Madrid, p. 146).

En la misma línea que en el resto de sus novelas, por tanto, Muñoz Molina utiliza de nuevo un personaje que, dentro de la obra, escucha lo que otro tiene que contarle. El interés del lector intratextual se contagia al lector extratextual que, como él, desea que le sigan contando.

Este interés por la narración oral se da también en una de las novelas cortas más entretenida y mejor escrita de Muñoz Molina: la obra perteneciente al género fantástico Carlota Fainberg. En esta novela existen dos narradores preocupados en contar su propia historia: Claudio y Marcelo Abengoa. La historia de Claudio no tiene un lector intratextual: es la historia de un timorato profesor de literatura que quiere ascender en la jerarquía académica, aunque sea a costa de su idiosincrasia española, que, según las universidades americanas, encierran todavía todo el machismo de siglos y el mismo sentimiento de superioridad del colonizador. La historia de Marcelo, en cambio, sí encuentra un lector intratextual, el propio Claudio: Abengoa cuenta su aventura amorosa con Carlota Fainberg, una porteña de piernas largas dueña de un hotel bonaerense. Probablemente, la insípida, aunque no por ello menos trágica, historia de Claudio, no sólo no encuentra lector intratextual, sino que no encontraría lector real si no fuera por la historia intercalada de Marcelo Abengoa. 
Claudio se plantea el encuentro con el empresario español en el aeropuerto de Pittsburgh como un reto intelectual. Por un lado, intenta descubrir toda la carga machista y políticamente incorrecta que portan las palabras del empresario; y, por otro lado, realiza un análisis narratológico de la historia de Carlota, utilizando para ello todas las teorías -normalmente disparatadas y pedantes- que encuentra a mano. De hecho, cada vez que interviene Claudio, el lector extratextual tiene la impresión de estar leyendo un texto académico, de asistir al estilo propio de una conferencia, basada, además, en estudios críticos inverosímiles como consecuencia del miedo de Claudio a saltar la barrera de lo políticamente correcto. Cualquiera de sus comentarios a la narración de Abengoa puede ser de utilidad:

Es obvio que no me ahorró a continuación ningún detalle sobre su performance, que aun pareciéndole a él inusitados y hasta triunfales seguían muy estrechamente las secuencias narrativas de esas adults movies que ahora están empezando a estudiarse incluso en algunos circunspectos departamentos de español como muestras de la retórica del exceso que subyace al discurso pornográfico. [...]

Llegando al clímax de su relato, Abengoa se olvidaba de todo, hasta de que dicho relato presuponía un destinatario, es decir, yo. [...] Abengoa tenía en la cara una sonrisa casi obscena de satisfacción, que me hizo pensar en la discutida, aunque tentadora tesis de Andrea Billington sobre una posible textual ejaculation ${ }^{31}$.

Los destinatarios de la historia de cada uno de los personajes son distintos. El destinatario de Abengoa es aquel que se deja llevar por las historias sencillas, que pretende solamente entretenerse, pasar, en este caso, un rato agradable mientras espera con fastidio que amaine la tormenta y se anuncie su vuelo. Parece entonces que el destinatario elegido por Abengoa para que sea su receptor no es el más apropiado. Los prejuicios y los complejos pseudointelectuales de Claudio no le permiten disfrutar de este tipo de relatos: en primer lugar, porque es un relato machista donde se narran las conquistas amorosas de un hombre; en segundo lugar, porque es una historia lineal donde no hay ningún tipo de complejidad estilística. A pesar de eso, y como decía Muñoz Molina citando a Proust, el buen arte crea a su público converso ${ }^{32}$. Efectivamente, el empresario logra atrapar al profesor en su relato y hacerlo que se interese. De esta manera, Marcelo ha sido capaz de convertir a su único lector.

${ }^{31}$ A. Muñoz Molina, Carlota Fainberg, Madrid, Punto de Lectura, 2001, pp. 88-89. En adelante se citará en el texto, entre paréntesis, por esta edición.

${ }^{32}$ J. M. Begines Hormigo, "Conversaciones con Muñoz Molina”, art. cit., p. 10. 
Determinar a quién va dirigida la narración de Claudio quizá sea más difícil. Parece que se dirige exclusivamente a aquellos que viven de la literatura, que se sirven de la literatura como apoyo para montar sus elucubraciones. No hay narración más sencilla que la de Abengoa; no obstante, utiliza las teorías más peregrinas que tiene a mano para comentarla. Claudio construye una elaborada divagación donde sólo existe la profundidad en apariencia, en la terminología y en los tecnicismos utilizados. Pues bien, Claudio espera tener como destinatario de esas reflexiones acerca del relato de Abengoa a otros que, como él, utilizan la literatura como lucimiento intelectual, sin saber, a pesar de ello, disfrutar estéticamente de una buena historia.

Sin embargo, no puede asegurarse que sea ese su destinatario porque, en efecto, en algunas ocasiones Claudio reconoce las locuras de ciertas teorías y la complejidad vacua e ininteligible de sus planteamientos. Esas confesiones -que se realizan también en el orden de lo políticamente correcto, contrariándolo en algunos momentos- no pueden estar dirigidas a un lector, real o ficticio, que se toma en serio ciertas teorías, porque sería una ofensa para él:

[Abengoa] era capaz de leer balances e informes financieros sobre el input y el output y el cashflow que para mí habrían sido sin duda tan incomprensibles como los escritos teóricos de José Lezama Lima, por poner un ejemplo que espero no sea interpretado como antilatinoamericano (Carlota Fainberg, pp. 43-44).

Entonces, a quién dirige Claudio sus comentarios narratológicos de la historia de Abengoa, a quién le cuenta sus sentimientos íntimos acerca de su frustración profesional, a quién le describe lo que vio y supo en el hotel donde Abengoa mantuvo relaciones con Carlota. Pues no se sabe. Puede que sea, simplemente, un monólogo interior en el que se mantienen sus convenciones propias, donde el personaje se reta a sí mismo, tantea hasta dónde llega su capacidad intelectual y se confiesa su propia ineptitud.

Además de esto, Claudio se introduce en la historia de Abengoa y conoce a la protagonista, a Carlota Fainberg, aunque descubre cosas ciertamente inesperadas: la historia de Carlota Fainberg no es más que una leyenda, real o inventada -los límites de la realidad y la ficción, como en toda la obra del ubetense se difuminan-, que se cuenta en un hotel de Buenos Aires. Desde el momento en que Claudio conoce la imposibilidad de que Abengoa haya vivido de verdad la historia que le ha contado, la novela toma un cariz ciertamente fantástico que llena de dudas al lector real: si Abengoa logró engañar a Claudio -y al lector real por extensión-, ¿no será posible que ahora el profesor de literatura, transformado en cierta manera por el relato de Marcelo, haya querido incrementar el mito, la leyenda, y añadir su aportación personal? A pesar de 
todos los prejuicios que lleva Claudio consigo al comienzo de la narración, puede decirse que se parece, en algunos aspectos, al lector modelo de Muñoz Molina: ha sido tocado y modificado por la magia de la ficción.

Otro punto interesante, en relación con el destinatario de las distintas narraciones, es a quién dirige el autor real, Muñoz Molina, su novela corta. Dice William Sherzer que "seems to be directed towards a bilingual reader, but Muñoz Molina's audience is not bilingual. It is thus a Spanish speaking reader with some knowledge of basic English terms that the narrative seems aimed at" ${ }^{\text {"33 }}$. Efectivamente, la obra del ubetense está plagada de neologismos, la mayoría de ellos innecesarios. Sólo hace falta abrir el libro para percatarse de esta constante cada vez que habla Claudio: "Aislado no se sabía para cuánto tiempo por uno de los blizzards más tremendos del siglo, según repetían con victorioso entusiasmo los weather men (y women) de la televisión. Me veía a mí mismo como enfrentado a un case study" (Carlota Fainberg, p. 63). Por otra parte, es totalmente cierto que quien tenga ciertas nociones básicas del inglés no tendrá ningún problema en entender lo que dice el profesor.

El ámbito de la recepción de la obra, no obstante, podría circunscribirse a un campo más determinado, teniendo en cuenta las palabras de Sherzer, que mantiene que la intención de la obra es "to ridicule that particular reader: the snobbish Spanish professorial type that Muñoz Molina encountered repeatedly in his travels throughout the American academy" ${ }^{34}$. En atención a estas palabras, el lector real a quien Muñoz Molina dirige su obra no sólo es un lector que tiene nociones básicas del inglés, sino un lector que, además, tiene ciertas ideas elementales acerca de la crítica literaria y de las modas críticas actuales. El destinatario de esta obra debe ser consciente del acoso de lo políticamente correcto, que llega a bloquear, en momentos determinados, la lengua de Claudio. Es muy divertido e ilustrativo el siguiente fragmento, donde el profesor, que habla inocentemente, es recriminado por Morini, el chairman del departamento:

- Hay otros problemas, Claudio [...] Sospechas de racismo. De cierto race bias, al menos.

- Pero eso es una calumnia [...]

- Esa estudiante tuya, Ayesha algo...

${ }^{33}$ W. Sherzer, “Antonio Muñoz Molina's «Carlota Fainberg»: an Ironic Manifesto", Romance Notes, 38 (1998), p. 288.

${ }^{34} I b .$, p. 288. 
- ¿Una chica negra, bastante gorda? -nada más decir esas palabras me arrepentí, comprendiendo que yo mismo estaba labrándome la perdición [...].

- «Una chica negra, bastante gorda». [...] ¿Quieres buscarme la ruina, Claudio, hablando de esa manera delante de mí? ¡Y luego te quejas de que te acusen de white supremacist! Esta chica African American, sobre cuyo aspecto físico no hay necesidad de hacer ninguna observación ofensiva y/o discriminatoria, vino a quejárseme porque le habías marcado su último paper con una C.

- Por lo menos la aprobé, ¿no? No sabe nada de nada. [...]

- La aprobaste, Claudio, qué palabra. Ustedes los españoles siempre aprobando y desaprobando a la gente, siempre con el espíritu de gran inquisidor (Carlota Fainberg, pp. 187-188).

El artículo de Sherzer es bastante acertado y se ciñe sobremanera a las intenciones del texto. Él sostiene que Carlota Fainberg es una burla irónica de la crítica literaria y de sus defectos pero, a la vez -mantiene en el último párrafo de su artículo- una defensa de ella, porque el texto literario necesita del comentario crítico. Por todo ello, el lector modelo de Muñoz Molina, en este caso, es aquel que se entrega sensatamente al disfrute de una buena historia -como en algún momento hizo Claudio ante lo que narra Abengoa-, el que utiliza las herramientas de la crítica no como una forma de vanidad, sino para obtener un mayor disfrute del texto. El lector de Carlota Fainberg debe coincidir en mayor o menor medida con la visión paródica que tiene Muñoz Molina sobre Claudio y el mundo académico en el que se mueve, para así poder reírse y divertirse con la fina ironía desplegada en la novela. Carlota Fainberg es, utilizando el título del artículo de Sherzer, un manifiesto irónico.

Como se habrá podido apreciar a lo largo de estas páginas, Antonio Muñoz Molina necesita que en sus novelas exista siempre -o en la mayoría de los casospersonajes que estén dispuestos a convertirse en receptores entusiastas de historias. La actitud de estos personajes oscila entre la actividad de aquellos que se transforman en verdaderos detectives, descubridores de las incógnitas del relato, y la de aquellos otros personajes que se limitan a oír con atención -y a realizar las operaciones propias de un lector extratextual- las palabras de la voz que les habla.

\section{REFERENCIAS BIBLIOGRÁFICAS.}

ACOSTA GÓMEZ, L. A., El lector y la obra, Madrid, Gredos, 1989. 
BEGINES HORMIGO, J. M., "Conversaciones con Muñoz Molina", Philologia Hispalensis, 18 (2004), pp. 7-20.

BEGINES HORMIGO, J. M., "La locura de Don Quijote en algunos personajes de Antonio Muñoz Molina”, en E. Torre (ed.), Medicina y Literatura V, Sevilla, Padilla Libros, 2006, pp. 133-149.

BEgINES HORMigO, J. M., Personajes y estilo en la narrativa de Antonio Muñoz Molina, Sevilla, Padilla Libros, 2006.

BERMÚDEZ, S., "Negro que te quiero rosa: La feminización de la novela de espías en Beltenebros", España Contemporánea, VII.2 (1994), pp. 7-25.

BOBES NAVES, M. C., "El personaje novelesco: cómo es, cómo se construye", en M. Mayoral (coord.), El personaje novelesco, Madrid, Ministerio de CulturaCátedra, 1993, pp. 43-68.

COLMEIRO, J. F., La novela policíaca española. Teoría e bistoria crítica, Barcelona, Anthropos, 1994.

FORSTER, E. M., Aspectos de la novela, Xalapa (México), Universidad Veracruzana, 1961.

HERZBERGER, D. K., "Reading and the Creation of Identity in Muñoz Molina's Beatus ille", Revista Hispánica Moderna, L.2 (1997), pp. 382-390.

ISER, W., "El proceso de lectura: enfoque fenomenológico", en J. A. Mayoral (comp.), Estética de la recepción, Madrid, Arco/Libros, 1987, pp. 215-243.

JAUSS, H. R., "El lector como instancia de una nueva historia de la literatura", en J. A. Mayoral (comp.), Estética de la recepción, Madrid, Arco/Libros, 1987, pp. 59-85.

KUNZ, M., “Anticipación y resonancia en El jinete polaco”, en I. Andrés-Suárez (ed.), Ética y estética de Antonio Muñoz Molina, número monográfico de Cuadernos de narrativa, 2 (1997), pp. 125-137.

LATORRE MADRID, M. A., La narrativa de Antonio Muñoz Molina. Beatus ille como metanovela, Málaga, Universidad de Málaga, 2003.

MUÑOZ MOLINA, A., Beatus ille, Barcelona, Seix Barral, 2002.

MUÑOZ MOLINA, A., Carlota Fainberg, Madrid, Punto de Lectura, 2001.

MUÑOZ MOLINA, A., El invierno en Lisboa, Barcelona, Seix Barral, 2003.

MUÑOZ MOLINA, A., El jinete polaco, Barcelona, Seix Barral, 2002.

MUÑOZ MOLINA, A., "La invención del personaje", en M. Mayoral (coord.), El personaje novelesco, Madrid, Ministerio de Cultura-Cátedra, 1993, pp. 87-90.

MUÑOZ MOLINA, A., Los misterios de Madrid, Barcelona, Seix Barral, 2002. 
OROPESA, S. A., La novelística de Antonio Muñoz Molina: sociedad civil y literatura lúdica, Jaén, Universidad de Jaén, 1999.

PRIETO, J., “«Playing the sedulous ape»: Antonio Muñoz Molina y los espejos de la (meta)ficción en Beatus ille”, Revista de estudios hispánicos, 36.2 (2002), pp. 425-456.

RICH, L., The narrative of Antonio Muñoz Molina. Self-Conscious Realism and "El Desencanto", New York, Peter Lang, 1994.

SÁNCHEZ, I., "Recursos de suspense en las novelas de Antonio Muñoz Molina”, en I. Andrés-Suárez (ed.), Ética y estética de Antonio Muñoz Molina, número monográfico de Cuadernos de narrativa, 2 (1997), pp. 93-106.

SHERZER, W., "Antonio Muñoz Molina's «Carlota Fainberg»: an Ironic Manifesto", Romance Notes, 38 (1998), pp. 287-293.

José Manuel Begines Hormigo

Fecha de recepción: 14/11/2006 jmbeghor@hotmail.com

Fecha de aceptación: 15/02/2007

Depto. Lengua Española, Lingüística t $\mathrm{T}^{\mathrm{a}}$ de la Literatura

Facultad de Filología (Universidad de Sevilla)

$\mathrm{C} /$ Palos de la Fra. s/n

41004 Sevilla (Spain) 